Article

\title{
Lignin Biodegradation in Pulp-and-Paper Mill Wastewater by Selected White Rot Fungi
}

\author{
Stefania Costa ${ }^{1}$, Davide Gavino Dedola ${ }^{1}$, Simone Pellizzari ${ }^{2}$, Riccardo Blo ${ }^{2}$, Irene Rugiero ${ }^{1}$, \\ Paola Pedrini ${ }^{1}$ and Elena Tamburini ${ }^{1, *}$ \\ 1 Department of Life Science and Biotechnology, University of Ferrara, Via L. Borsari, 44121 Ferrara, Italy; \\ stefania.costa@unife.it (S.C.); davidegavino.dedola@student.unife.it (D.G.D.); irene.rugiero@unife.it (I.R.); \\ pdp@unife.it (P.P.) \\ 2 NCR-Biochemical SpA, Via dei Carpentieri, 40050 Castello d'Argile (BO), Italy; \\ S.Pellizzari@ncr-biochemical.it (S.P.); R.Blo@ncr-biochemical.it (R.B.) \\ * Correspondence: tme@unife.it; Tel.: +39-0532-455-329
}

Received: 20 October 2017; Accepted: 29 November 2017; Published: 2 December 2017

\begin{abstract}
An investigation has been carried out to explore the lignin-degrading ability of white rot fungi, as B. adusta and P. crysosporium, grown in different media containing (i) glucose and mineral salts; (ii) a dairy residue; (iii) a dairy residue and mineral salts. Both fungi were then used as inoculum to treat synthetic and industrial pulp-and-paper mill wastewater. On synthetic wastewater, up to $97 \%$ and $74 \%$ of lignin degradation by B. adusta and P. crysosporium, respectively, have been reached. On industrial wastewater, both fungal strains were able to accomplish $100 \%$ delignification in 8-10 days, independent from $\mathrm{pH}$ control, with a significant reduction of total organic carbon (TOC) of the solution. Results have confirmed the great biotechnological potential of both B. adusta and P. crysosporium for complete lignin removal in industrial wastewater, and can open the way to next industrial applications on large scale.
\end{abstract}

Keywords: lignin; delignification; pulp-and-paper-mill c; wastewater; white rot fungi; B. adusta; P. crysosporium

\section{Introduction}

The pulp and paper industry in Europe accounts for about a quarter of world manufacturing, producing more than 90 million tons of paper and board, and more than 36 million tons of pulp annually [1]. The manufacture of paper generates significant quantities of wastewater, as high as $60 \mathrm{~m}^{3} /$ ton of paper produced [2]. These raw wastewaters-sometimes called black liquor-can be potentially very polluting [3]. Pulp-and-paper mill wastewater contains a considerable amount of pollutants characterized by high biochemical oxygen demand (BOD), chemical oxygen demand (COD), and high dissolved solids, mainly due to alkali-lignin and polysaccharide degradation residues [4]. The environmental impact of pulp-and-paper mill wastewater depends not only on its chemical nature, but also on its dark coloration that negatively affects aquatic fauna and flora [5]. The primary contributors to the color and toxicity of wastewater are high-molecular-weight lignin and its derivatives. Lignin is the generic term for a large group of aromatic rigid and impervious polymers resulting from the oxidative coupling of 4-hydroxyphenylpropanoids, present predominantly in woody plants [6]. The chemical or biological degradation of lignin is very difficult due to the presence of recalcitrant and not-hydrolysable carbon-carbon linkages and aryl ether bonds [7]. Notwithstanding, pulp-and-paper mills are now facing challenges to comply with stringent environmental regulations [8]. For years, various methods have been developed and attempted for wastewater treatment and organic pollutants removal, including incineration [9], photochemical $\mathrm{UV} / \mathrm{TiO}_{2}$ oxidation [10], adsorption of organic compounds on activated carbon and polymer resin [11], chemical coagulation/flocculation 
of lignin using synthetic or natural coagulants [12], and catalytic wet air oxidation [13]. However, all these processes are expensive, environmentally overburdening, and often not very efficient [14]. Furthermore, in these processes lignin is not really degraded, but transferred from a water-suspended state into a solid or absorbed state, only moving the problem [15]. A valid alternative to remove organic pollutants from pulp-and-paper wastewater is now represented by biological treatments. In nature, various ligninolytic organisms and enzymes including fungi, actinomycetes, and bacteria are implicated in lignin biodegradation, and can have potential application in wastewater treatments [16]. Several studies have been carried out on biological delignification of pulp-and-paper mill wastewater using pure bacterial strains [17]: about $70-80 \%$ of lignin degradation and COD removal have been achieved with Pseudomonas putida and Acinetobacter calcoaceticus [18], Aeromonas formicans [19], and Bacillus sp. [20]. In this field, white-rot fungi have also received increasing attention due to their powerful lignin-degrading enzyme system [21]. White-rot wood fungi use the cellulose fraction as a carbon source and are able to completely degrade the lignin in order to have access to the cellulose. Basidiomycetes species are extensively studied due to the high degradation ability of the extracellular oxidative enzymes (i.e., laccase, peroxidase) that need low-molecular weight cofactors [22]. Recent developments of new technologies and/or improvements of existing ones for the treatment of effluents from the pulp and paper industries include the use of the white rot fungi Aspergillus foetidus, Phanerochaete chrysosporium, and Trametes versicolor [23], but scarce industrial experience is available concerning the degradation of highly-contaminated pulp-and-paper mill wastewater by fungi. In particular, Phanerochaete chrysosporium is a well-known white-rot fungus and a strong degrader of various xenobiotics [24]. It has been extensively investigated as a model organism for fungal lignin and organopollutant degradation, since it was the first fungus found to produce lignin peroxidase and manganese peroxidase [25]. Bjerkandera adusta is a wood-rotting basidiomycete belonging to the white-rot fungi commonly found in Europe. Its capability to degrade aromatic xenobiotics [26] and extractives [27] has progressively increased its biotechnological interest in wastewater treatments for lignin degradation [28]. Due to its laccase and manganese peroxidase activity [29,30], applications of B. adusta to the biomineralization of lignin in soils [31] and to the decoloration of industrial dye effluents [32] has been already attempted, but to date not at an industrial level. This study reports the lignin removal capability and effectiveness of B. adusta and P. crysosporium, grown in different culture media containing lignin, on synthetic and industrial pulp-and-paper mill wastewater.

\section{Materials and Methods}

\subsection{Fungal Strain Master Cell Bank and Working Cell Bank}

Bierkandera adusta and Phenarochete crysosporium were purchased from Leibniz Institute DSMZ-German Collection of Microorganisms and Cell Cultures (Braunschweig, Germany). The strains have been stored as a master cell bank (MCB), maintained at $-20^{\circ} \mathrm{C}$ in $3 \%$ malt extract and $3 \%$ peptone cryovials $(1 \mathrm{~mL})$ with added glycerol $(0.5 \mathrm{~mL})$. Cells from the MCB were expanded to form the working cell bank (WCB), using an identical procedure. Prior to being used in the process, the fungal strains from WCB were maintained for 7 days in $3 \%$ malt extract agar Petri dishes.

\subsection{Standard Media and Pulp-and-Paper Mill Wastewater}

Three growth media have been prepared for this study: (i) a medium (standard glucose medium, SGM) containing glucose $(10 \mathrm{~g} / \mathrm{L}), \mathrm{KH}_{2} \mathrm{PO}_{4}(1 \mathrm{~g} / \mathrm{L})$, yeast extract $(0.5 \mathrm{~g} / \mathrm{L}), \mathrm{MgSO}_{4} 7 \mathrm{H}_{2} \mathrm{O}(0.5 \mathrm{~g} / \mathrm{L})$, and $\mathrm{KCl}(0.5 \mathrm{~g} / \mathrm{L})$ was adjusted to $\mathrm{pH} 5.5$ with $1 \mathrm{M} \mathrm{HCl}$ and autoclaved; (ii) a medium (standard lactose medium, SLM) where glucose has been replaced with $50 \mathrm{~mL}$ of a dairy residue from cheese processing containing $50 \mathrm{~g} / \mathrm{L}$ lactose, supplied by Granarolo S.p.A. (Bologna, Italy) (Table 1); (iii) a medium made up with the sole dairy by-product (standard dairy medium, SDM). Before inoculation, SGM medium was added with $5 \mathrm{~g} / \mathrm{L}$ of standard lignin. Spore and mycelium suspensions obtained from agar Petri dishes were used to inoculate a $250 \mathrm{~mL}$ Erlenmeyer flask containing $100 \mathrm{~mL}$ of SGM. Cell cultures were 
all incubated at $24^{\circ} \mathrm{C}$ without $\mathrm{pH}$ control for 10 days under mild stirring rate (60 rpm) and samples were withdrawn at 1-3 day intervals for residual lignin content analysis.

Table 1. Dairy residue chemical composition.

\begin{tabular}{cc}
\hline Constituent & \% \\
\hline Total solids & 6.0 \\
Lactose & 5.0 \\
Proteins & 0.6 \\
Non-protein N & 0.2 \\
Lipids & 0.05 \\
Ash & 0.5 \\
\hline Note: ${ }^{*} \mathrm{~N}=$ Nitrogen.
\end{tabular}

A synthetic pulp-and-paper mill wastewater was prepared by dissolving $5 \mathrm{~g} / \mathrm{L}$ of standard lignin in distilled water. Three 1-L Erlenmeyer flasks containing $500 \mathrm{~mL}$ of the synthetic wastewater were inoculated with $50 \mathrm{~mL}$ of cell cultures grown in the SGM, SLM, and SDM media, respectively, all added with standard lignin $(5 \mathrm{~g} / \mathrm{L})$ and incubated for 10 days at $24^{\circ} \mathrm{C}$ and mild agitation $(60 \mathrm{rpm})$.

The industrial pulp-and-paper mill wastewater utilized for this study was supplied by a local pulp-and-paper firm, collected in a closed container and stored in darkness at $4{ }^{\circ} \mathrm{C}$ until use. The concentration of soluble and insoluble lignin was determined, as well as total organic carbon (TOC), as described in Section 2.3.

Two 1-L Erlenmeyer flasks containing $500 \mathrm{~mL}$ of wastewater were inoculated with $50 \mathrm{~mL}$ of cell cultures grown in the SLM added with lignin $(5 \mathrm{~g} / \mathrm{L})$, and incubated for 10 days at $24{ }^{\circ} \mathrm{C}$ and mild agitation (60 rpm). In one flask, $\mathrm{pH}$ was adjusted to 5.5 with $1 \mathrm{M} \mathrm{HCl}$, in the other $\mathrm{pH}$ was left at the original value measured for industrial wastewater of 6.5 without control.

All of the above experiments were conducted in triplicate. The data in subsequent sections are based on the average and standard deviation of the three measurements.

\subsection{Chemicals and Analysis}

All chemicals were reagent grade or better. Unless specified otherwise, they were obtained from Sigma-Aldrich Chemical Co (Saint Louis, MO, USA). The concentration of lignin was measured using the INNVENTIA—Biorefinery Test Methods L 2:2016 [33], specific for the determination of lignin isolated from a Kraft pulping process. The procedure is based on the sulphuric acid hydrolysis of the samples. This method makes it possible to determine concentrations of total lignin content, measured as the sum of the amount of acid-insoluble matter (AIM) and acid-soluble matter (ASM) after sulphuric acid hydrolysis, down to $10 \mathrm{mg} / \mathrm{g}$ oven-dry sample.

TOC was determined with a Carbon Analyzer TOC-V-CSM (Shimadzu, Tokio, Japan) after acidification with $2 \mathrm{M} \mathrm{HCl}$ to remove dissolved carbonate [34]. The instrument has a detection limit of $5 \mu \mathrm{g} / \mathrm{L}$ and a measurement accuracy expressed as coefficient of variation (CV) 1.5\%. Biomass concentration (dry weight, DW) was determined gravimetrically after drying overnight at $105^{\circ} \mathrm{C}$ on a pre-weighed $0.2 \mu \mathrm{m}$ filter.

\section{Results}

\subsection{B. adusta and P. crysosporium Growth on SGM}

Lignin was added to the standard medium SGM before inoculation of B. adusta and P. crysosporium because several studies describe that the presence of lignin in the liquid medium exerts an influence on the expression profile of lignin peroxidase, manganese peroxidase, and laccase-all enzymes held responsible for the lignin degradation of natural lignocellulosic residue [35,36]. Under the condition 
maintained on $100 \mathrm{~mL}$-scale, in 10 days B. adusta was able to uptake and metabolize lignin up to $67 \%$, while $P$. crysosporium only $30 \%$ (Figure 1 ).

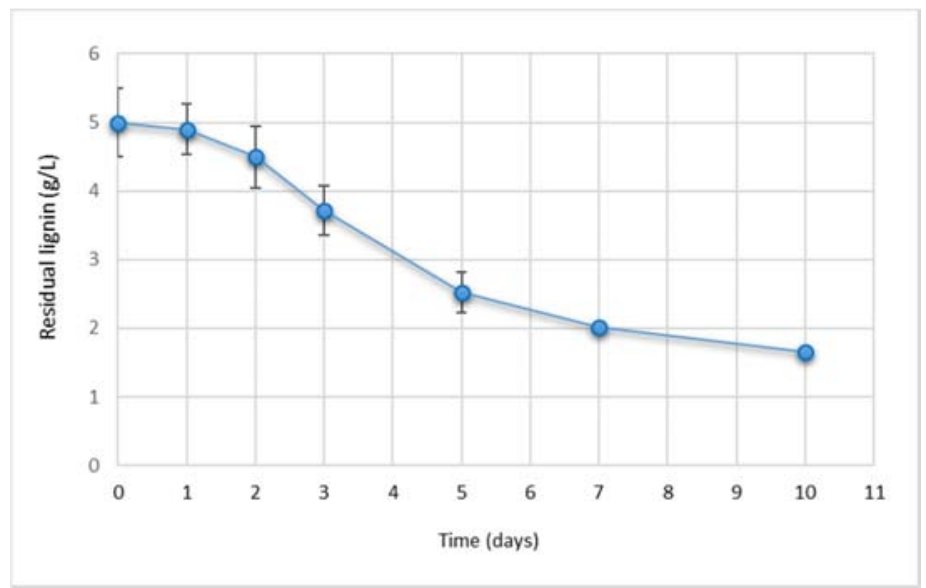

(a)

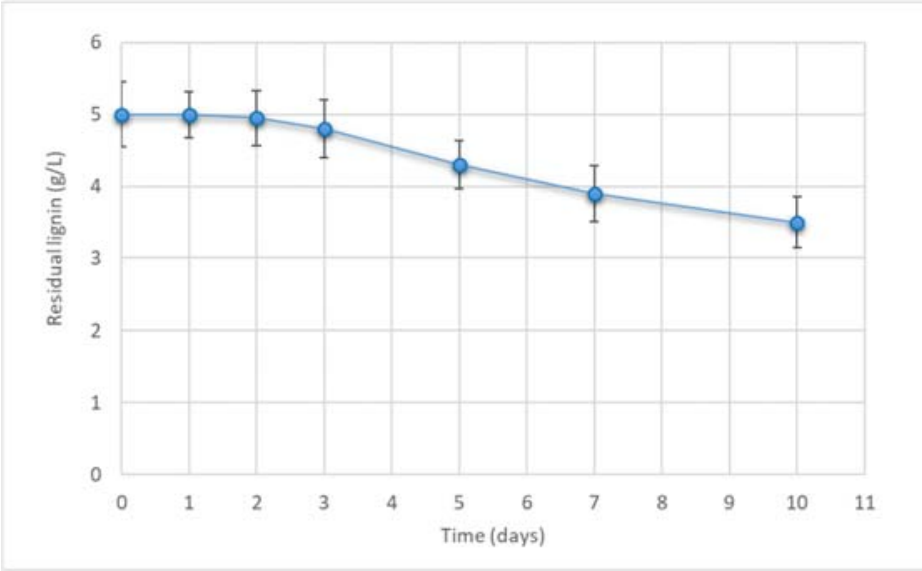

(b)

Figure 1. Lignin removal from $100 \mathrm{~mL}$ of standard glucose medium (SGM) with lignin $5 \mathrm{~g} / \mathrm{L}$ added by (a) B. adusta and (b) P. crysosporium.

As described by Girard et al. [37], in both cases the expression of delignifying enzymes only initiated after 2-3 days from inoculation, corresponding to complete glucose depletion (data not shown).

\subsection{Lignin Removal Efficiency on Synthetic Pulp-and-Paper Mill Wastewater}

The addition of agro-food by-products to fungal cultures may reflect complex growth conditions close to nature, and could stimulate the secretion of various enzymes required for degradation or detoxification processes [38]. This, in addition to the evidence that the production of lignin peroxidase and manganese peroxidase in B. adusta is stimulated by the presence of organic nitrogen $(\mathrm{N})$ source (unlike P. chrysosporium, which produces ligninolytic peroxidases in response to $\mathrm{N}$ limitation [39]), has driven the study towards the possibility of integrating the growth medium with a dairy by-product, usually rich in protein and amino acids, apart from sugar. Furthermore, in view of industrial application, the use of a by-product instead of pure substrates could permit the considerable reduction of operational investments, among which chemicals required for fungal growth are the most relevant. The use of cheese whey has been previously proposed by Feijoo et al. [40] as an inexpensive substrate for fungal growth. B. adusta and P. chrysosporium have been incubated in SGM, SLM, and only dairy 
residue with no addition of other nutrients or mineral salts (SDM). The largest amount of fungal biomass was obtained when dairy residue was present in the media (Table 2).

Table 2. Fungal cells dry weight (g/L) obtained from growth in SGM, standard lactose medium (SLM), and standard dairy medium (SDM) media.

\begin{tabular}{cccc}
\hline Strain & SGM & SLM & SDM \\
\hline B. adusta & $2.5 \pm 0.4$ & $3.6 \pm 0.5$ & $3.5 \pm 0.4$ \\
P. crysosporium & $2.7 \pm 0.3$ & $4.3 \pm 0.5$ & $3.8 \pm 0.6$ \\
\hline
\end{tabular}

In both cases, the results seem to confirm the correlation between organic $\mathrm{N}$ source and fungal cell growth. Identical amounts of cells of B. adusta and P. crysosporium grown in the three media were used as inoculum for synthetic wastewater, in order to verify if cell cultures developed in different media would express different enzymatic patterns or different enzyme activities. Figure 2a shows that B. adusta grown in the SGM medium was able to remove $73 \%$ of lignin, whilst $B$. adusta grown in the presence of a source of protein and amino acids in both cases reached delignification yields of $97 \%$ with SLM and $86 \%$ with SDM. On the other hand, P. crysosporium in all three cases obtained yields not higher than $74 \%$ when grown in SLM (54\% in SGM and 69\% in SDM, respectively).

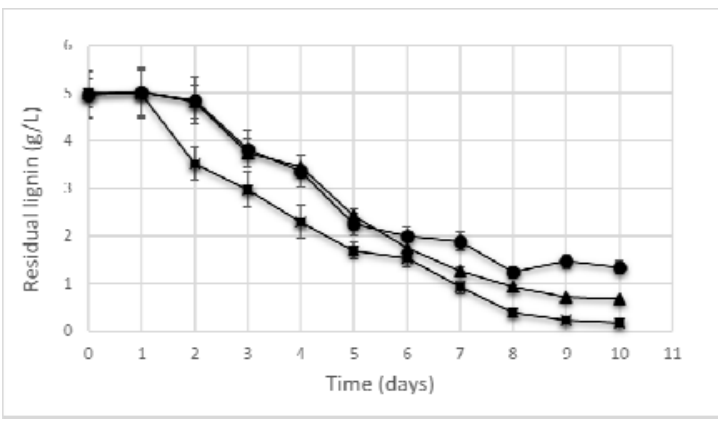

(a)

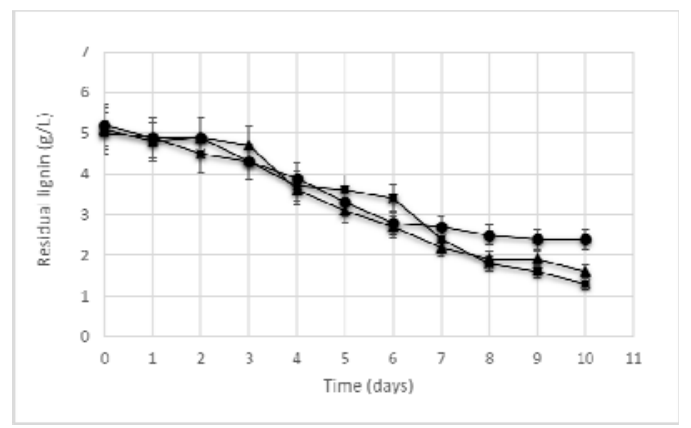

(b)

Figure 2. Lignin removal from synthetic pulp-and-paper mill wastewater during 10 days by (a) B. adusta and (b) P. crysosporium grown in SGM (dots), SDM (triangles), and SLM (squares) media, all with the addition of $5 \mathrm{~g} / \mathrm{L}$ lignin.

The time courses of delignification in 10 days were quite similar in all three cases for B. adusta, having a 1-day reduced lag phase cell culture grown in SLM. The interesting point is that the slopes of the three curves are similar in the 3-8 days' interval, but from day- 8 on, cell culture grown in SGM seemed to miss the lignin removal capacity, even though residual lignin was still present in the fermentation broth. This could be due to the decline of lignin peroxidase activity caused by the appearance of extracellular protease activity that has been observed after day 6-10 in cultures of P. chrysosporium grown on glucose [41]. This also confirmed what was reported by Nakamura et al. [42], whereby in glucose-based media, enzymes produced by B. adusta can only degrade part of the chemical structure of lignin. Otherwise, in order to maximize peroxidase activity, lactose has already been identified as a good carbon source for Bierkandera spp. when the nitrogen source was organic [43], as in SLM and SDM media. P. crysosporium was found to be surprisingly less active than B. adusta in lignin removal effectiveness in all three growth conditions (Figure 2b). Moreover, it showed a longer lag phase before starting to degrade lignin. According to Keyser et al. [44], lignin metabolism in P. crysosporium did not reflect the depletion of glucose, as in B. adusta, but instead appeared to be a response to nitrogen starvation. The prolonged lag phase could be induced by the need to wait for the partial or complete depletion of the $\mathrm{N}$ source transferred with inoculum. 


\subsection{Lignin Removal Efficiency on Industrial Pulp-and-Paper Mill Wastewater}

B. adusta grown on SLM with lignin $5 \mathrm{~g} / \mathrm{L}$ added has demonstrated to be effective for almost complete lignin biodegradation in synthetic wastewater. Based on these promising results, an application on industrial wastewater has been attempted, in comparison with P. crysosporium grown in the same conditions. The industrial wastewater supplied by the local pulp-and-paper mill for these tests ( $\mathrm{pH} 6.5$ and with a $100 \mathrm{~g} / \mathrm{L}$ lignin content on dry weight basis) was diluted (12\% dry weight). The ability of both fungal strains to biodegrade lignin has been tested, verifying the effect of $\mathrm{pH}$ on their enzymatic activities. In one case, the $\mathrm{pH}$ of wastewater was adjusted to the optimum value for fungi cell growth ( $\mathrm{pH}$ 5.5), and in the other the process was allowed to proceed without correction ( $\mathrm{pH}$ 6.5). From the perspective of industrial application, the possibility of avoiding costs deriving from the use of acids as correction agent could be very relevant. The results of the tests carried out using an inoculum of B. adusta and P. crysosporium grown on SLM medium on industrial wastewater with and without $\mathrm{pH}$ correction are reported in Figure 3.

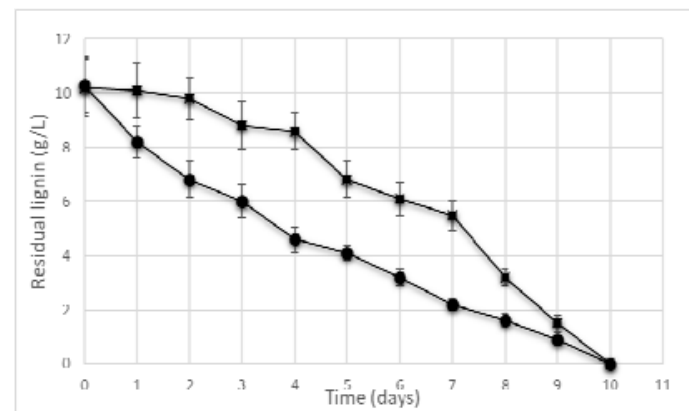

(a)

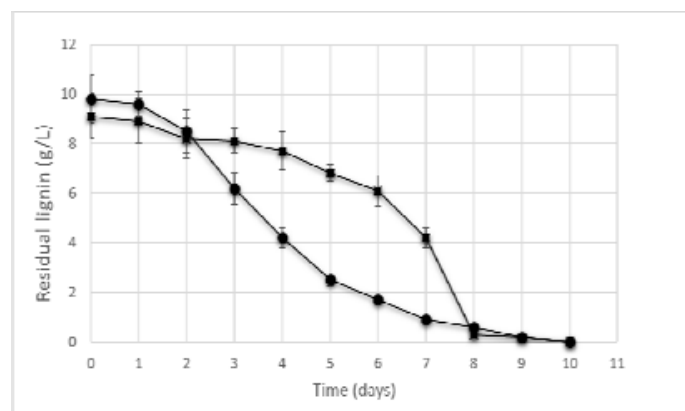

(b)

Figure 3. Lignin removal from industrial pulp-and-paper mill wastewater with $\mathrm{pH}$ correction (dots) and without $\mathrm{pH}$ correction (squares) during 10 days by (a) B. adusta and (b) P. crysosporium, grown in SLM medium added with lignin $5 \mathrm{~g} / \mathrm{L}$.

As expected, at optimum $\mathrm{pH}$ condition B. adusta started to biodegrade lignin without any lag phase and maintained an almost constant biodegradation rate of about $1 \mathrm{~g} / \mathrm{L}$ of lignin per day over the entire test course. In contrast, without $\mathrm{pH}$ control fungal cells needed 1-2 days for adapting, before starting biodegradation. This leads to a variable delignification rate during the process-slower at the beginning $(0.9 \mathrm{~g} / \mathrm{L} \times$ day $)$ and higher from five days on $(1.7 \mathrm{~g} / \mathrm{L} \times$ day). The final result in both cases was complete lignin removal, with an efficiency of $100 \%$. One hundred percent delignification was also obtained when treating the pulp-and-paper mill wastewater with P. crysosporium, almost complete in 8 days. At a first glance, the time courses seemed to confirm the previous results obtained on synthetic pulp-and-paper mill wastewater, regarding the need of a longer lag phase compared with B. adusta. Otherwise, a sharp decline of residual lignin was observed from day 6 . These results appeared to be particularly promising, compared with an average delignification yield of $70-80 \%$ reported for white rot fungi: both P. crysosporium and B. adusta were competitive against the $71 \%$ delignification yield on pulp-and-paper mill residues obtained by Pseudomonas putida [45], 78\% by Aeromonas formicans [19], and $80 \%$ by Acinetobacter calcoaceticus [46].

To confirm the overall organic $C$ removal, TOC analysis of samples was carried out. It is usually reported that lignin represents about $30-45 \%$ of the total organics in pulp-and-paper mill wastewater [47], so a corresponding decrease of TOC was expected (Figure 4). In both cases, an overall reduction of about $35 \%$ of organic charge of wastewater was obtained, reasonably due to lignin uptake for fungal metabolism. 


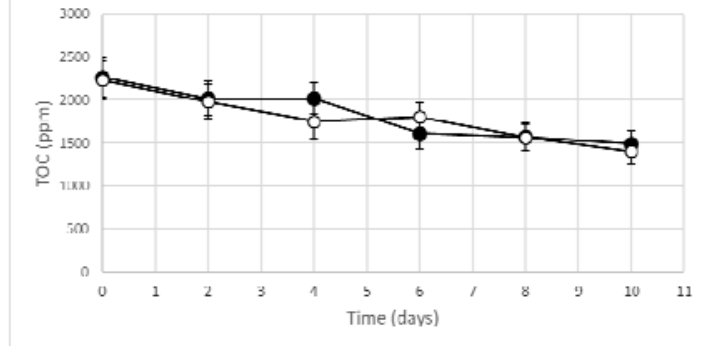

(a)

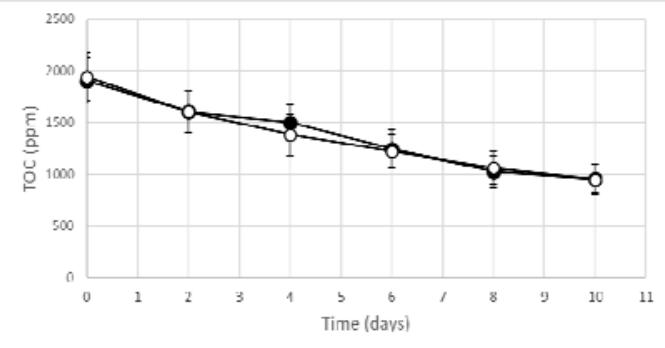

(b)

Figure 4. Total organic carbon (TOC) decrease of industrial pulp-and-paper mill wastewater with $\mathrm{pH}$ correction (white dots) and without $\mathrm{pH}$ correction (black dots) during 10 days by (a) B. adusta and (b) P. crysosporium grown in SLM medium with $5 \mathrm{~g} / \mathrm{L}$ lignin added.

\section{Conclusions}

This study opens new perspectives for the bioremediation of industrial effluents such as pulp-and-paper mill wastewater using white rot fungi. In particular both B. adusta and P. crysosporium were found able to growth on non-conventional media, better than on glucose as sole carbon source, and to improve the delignifying activity in the presence of organic $\mathrm{N}$ and mineral salts. Moreover, they can survive on synthetic wastewater and proved to be effective for the complete degradation of lignin. The biotechnological potential of these strains was also confirmed on industrial wastewater, being active up to the total depletion of lignin. No operational problem was detected at $500 \mathrm{~mL}$ scale, as a first confirmation of the robustness and applicability of this system. The results obtained lay the ground for further scaling up to pilot plant level.

Author Contributions: Davide Gavino Dedola, Riccardo Blo and Irene Rugiero performed all the experiments and carried out all the analytical assays, also giving a great contribution to the discussion. Simone Pellizzari conceived and designed the experiments, together with Stefania Costa and Elena Tamburini, who wrote the manuscript. As supervisor of the research group, Paola Pedrini defined the general research statement.

Conflicts of Interest: The authors declare no conflict of interest.

\section{References}

1. Key Statistics 2015. CEPI-Confederation of European Paper Industries. Available online: http:/ / www.cepi. org/statistics/keystatistics2015 (accessed on 9 October 2017).

2. Pokhrel, D.; Viraraghavan, T. Treatment of pulp and paper mill wastewater-A review. Sci. Total Environ. 2004, 333, 37-58. [CrossRef] [PubMed]

3. Thompson, G.; Swain, J.; Kay, M.; Forster, C.F. The treatment of pulp and paper mill effluent: A review. Bioresour. Technol. 2011, 77, 275-286. [CrossRef]

4. Lara, M.A.; Rodríguez-Malaver, A.J.; Rojas, O.J.; Holmquist, O.; González, A.M.; Bullón, J.; Araujo, E. Black liquor lignin biodegradation by Trametes elegans. Int. Biodeterior. Biodegrad. 2003, 52, 167-173. [CrossRef]

5. Ali, M.; Sreekrishnan, T.R. Aquatic toxicity from pulp and paper mill effluents: A review. Adv. Environ. Res. 2001, 5, 175-196. [CrossRef]

6. Vanholme, R.; Demedts, B.; Morreel, K.; Ralph, J.; Boerjan, W. Lignin biosynthesis and structure. Plant Physiol. 2010, 153, 895-905. [CrossRef] [PubMed]

7. Minu, K.; Jiby, K.K.; Kishore, V.V.N. Isolation and purification of lignin and silica from the black liquor generated during the production of bioethanol from rice straw. Biomass Bioenergy 2012, 39, $210-217$. [CrossRef]

8. Kamali, M.; Khodaparast, Z. Review on recent developments on pulp and paper mill wastewater treatment. Ecotoxicol. Environ. Saf. 2015, 114, 326-342. [CrossRef] [PubMed]

9. Harila, P.; Kivilinna, V.A. Biosludge incineration in a recovery boiler. Water Sci. Technol 1999, 40, $195-200$.

10. Chang, C.N.; Ma, Y.S.; Fang, G.C.; Chao, A.C.; Tsai, M.C.; Sung, H.F. Decolorizing of lignin wastewater using the photochemical UV/ $\mathrm{TiO}_{2}$ process. Chemosphere 2004, 56, 1011-1017. [CrossRef] [PubMed] 
11. Zhang, Q.; Chuang, K.T. Adsorption of organic pollutants from effluents of a Kraft pulp mill on activated carbon and polymer resin. Adv. Environ. Res. 2001, 5, 251-258. [CrossRef]

12. Wang, J.P.; Chen, Y.Z.; Wang, Y.; Yuan, S.J.; Yu, H.Q. Optimization of the coagulation-flocculation process for pulp mill wastewater treatment using a combination of uniform design and response surface methodology. Water Res. 2011, 45, 5633-5640. [CrossRef] [PubMed]

13. Sales, F.G.; Abreu, C.A.M.; Pereira, J.A.F.R. Catalytic wet-air oxidation of lignin in a three-phase reactor with aromatic aldehyde production. Braz. J. Chem. Eng. 2004, 21, 211-218. [CrossRef]

14. Wu, J.; Xiao, Y.Z.; Yu, H.Q. Degradation of lignin in pulp mill wastewaters by white-rot fungi on biofilm. Bioresour. Technol. 2005, 96, 1357-1363. [CrossRef] [PubMed]

15. Puyol, D.; Batstone, D.J. Resource Recovery from wastewater by biological technologies. Front. Microbiol. 2017, 8. [CrossRef] [PubMed]

16. Ruiz-Dueñas, F.J.; Martínez, Á.T. Microbial degradation of lignin: How a bulky recalcitrant polymer is efficiently recycled in nature and how we can take advantage of this. Microb. Biotechnol. 2009, 2, 164-177. [CrossRef] [PubMed]

17. Brown, M.E.; Chang, M.C. Exploring bacterial lignin degradation. Curr. Opin. Chem. Biol. 2014, $19,1-7$. [CrossRef] [PubMed]

18. Jain, N.; Shrivastava, A.K.; Srivastava, S.K. Treatment of black liquor by Pseudomonas putida and Acinetobacter calcoaceticus in continuous reactor. Environ. Technol. 1996, 17, 903-907. [CrossRef]

19. Gupta, V.K.; Minocha, A.K.; Jain, N. Batch and continuous studies on treatment of pulp mill wastewater by Aeromonas formicans. J. Chem. Technol. Biotechnol. 2001, 76, 547-552. [CrossRef]

20. Raj, A.; Reddy, M.K.; Chandra, R. Identification of low molecular weight aromatic compounds by gas chromatography-mass spectrometry (GC-MS) from kraft lignin degradation by three Bacillus sp. Int. Biodeterior. Biodegrad. 2007, 59, 292-296. [CrossRef]

21. Leonowicz, A.; Matuszewska, A.; Luterek, J.; Ziegenhagen, D.; Wojtaś-Wasilewska, M.; Cho, N.S.; Rogalski, J. Biodegradation of lignin by white rot fungi. Fungal Genet. Biol. 1999, 27, 175-185. [CrossRef] [PubMed]

22. Kirk, T.K.; Farrell, R.L. Enzymatic "combustion": The microbial degradation of lignin. Ann. Rev. Microbiol. 1987, 41, 465-501. [CrossRef] [PubMed]

23. Fu, Y.; Viraraghavan, T. Fungal decolorization of dye wastewaters: A review. Bioresour. Technol. 2001, 79, 251-262. [CrossRef]

24. Sağlam, N.; Say, R.; Denizli, A.; Patır, S.; Arıca, M.Y. Biosorption of inorganic mercury and alkylmercury species on to Phanerochaete chrysosporium mycelium. Proc. Biochem. 1999, 34, 725-730. [CrossRef]

25. Faison, B.D.; Kirk, T.K. Factors involved in the regulation of a ligninase activity in Phanerochaete chrysosporium. App. Environ. Microbiol. 1985, 49, 299-304.

26. Sodaneath, H.; Lee, J.I.; Yang, S.O.; Jung, H.; Ryu, H.W.; Cho, K.S. Decolorization of textile dyes in an air-lift bioreactor inoculated with Bjerkandera adusta OBR105. J. Environ. Sci. Health Part A 2017, 52, 1099-1111. [CrossRef] [PubMed]

27. Kinnunen, A.; Maijala, P.; JArvinen, P.; Hatakka, A. Improved efficiency in screening for lignin-modifying peroxidases and laccases of basidiomycetes. Curr. Biotechnol. 2017, 6, 105-115. [CrossRef]

28. Peláez, F.; Martínez, M.J.; Martinez, A.T. Screening of 68 species of basidiomycetes for enzymes involved in lignin degradation. Mycol. Res. 1995, 99, 37-42. [CrossRef]

29. Rodriguez, E.; Pickard, M.A.; Vazquez-Duhalt, R. Industrial dye decolorization by laccases from ligninolytic fungi. Curr. Microbiol. 1999, 38, 27-32. [CrossRef] [PubMed]

30. Wang, Y.; Vazquez-Duhalt, R.; Pickard, M.A. Purification, characterization, and chemical modification of manganese peroxidase from Bjerkandera adusta UAMH 8258. Curr. Microbiol. 2002, 45, 77-87. [CrossRef] [PubMed]

31. Tuomela, M.; Oivanen, P.; Hatakka, A. Degradation of synthetic 14 C-lignin by various white-rot fungi in soil. Soil Biol. Biochem. 2002, 34, 1613-1620. [CrossRef]

32. Anastasi, A.; Spina, F.; Prigione, V.; Tigini, V.; Giansanti, P.; Varese, G.C. Scale-up of a bioprocess for textile wastewater treatment using Bjerkandera adusta. Bioresour. Technol. 2010, 101, 3067-3075. [CrossRef] [PubMed]

33. Kraft Lignins_Lignin and Carbohydrate Content-Acid Hydrolysis Method. Available online: http:/ / www. innventia.com (accessed on 12 October 2017). 
34. Potter, B.B.; Wimsatt, J.C. Method 415.3. Determination of Total Organic Carbon and Specific UV Absorbance at $254 \mathrm{~nm}$ in Source Water and Drinking Water; EPA/600/R-05/055; US Environmental Protection Agency: Cincinnati, OH, USA, 2005.

35. Reina, R.; Kellner, H.; Jehmlich, N.; Ullrich, R.; García-Romera, I.; Aranda, E.; Liers, C. Differences in the secretion pattern of oxidoreductases from Bjerkandera adusta induced by a phenolic olive mill extract. Fungal Genet. Biol. 2014, 72, 99-105. [CrossRef] [PubMed]

36. Arora, D.S.; Chander, M.; Gill, P.K. Involvement of lignin peroxidase, manganese peroxidase and laccase in degradation and selective ligninolysis of wheat straw. Int. Biodeterior. Biodegrad. 2002, 50, 115-120. [CrossRef]

37. Girard, V.; Dieryckx, C.; Job, C.; Job, D. Secretomes: The fungal strike force. Proteomics 2013, 13, 597-608. [CrossRef] [PubMed]

38. Schützendübel, A.; Majcherczyk, A.; Johannes, C.; Hüttermann, A. Degradation of fluorene, anthracene, phenanthrene, fluoranthene, and pyrene lacks connection to the production of extracellular enzymes by Pleurotus ostreatus and Bjerkandera adusta. Int. Biodeterior. Biodegrad. 1999, 43, 93-100. [CrossRef]

39. Bonnarme, P.; Asther, M.; Asther, M. Influence of primary and secondary proteases produced by free or immobilized cells of the white-rot fungus Phanerochaete chrysosporium on lignin peroxidase activity. J. Biotechnol. 1993, 30, 271-282. [CrossRef]

40. Feijoo, G.; Moreira, M.T.; Roca, E.; Lema, J.M. Use of cheese whey as a substrate to produce manganese peroxidase by Bjerkandera sp. BOS55. J. Ind. Microbiol. Biotechnol. 1999, 23, 86-90. [CrossRef] [PubMed]

41. Dosoretz, C.G.; Chen, H.C.; Grethlein, H.E. Effect of environmental conditions on extracellular protease activity in lignolytic cultures of Phanerochaete chrysosporium. Appl. Environ. Microbiol. 1990, 56, 395-400. [PubMed]

42. Nakamura, Y.; Sungusia, M.G.; Sawada, T.; Kuwahara, M. Lignin-degrading enzyme production by Bjerkandera adusta immobilized on polyurethane foam. J. Biosci. Bioeng. 1999, 88, 41-47. [CrossRef]

43. Taboada-Puig, R.; Lú-Chau, T.; Moreira, M.T.; Feijoo, G.; Martínez, M.J.; Lema, J.M. A new strain of Bjerkandera sp. production, purification and characterization of versatile peroxidase. World J. Microbiol. Biotechnol. 2011, 27, 115-122. [CrossRef]

44. Keyser, P.; Kirk, T.K.; Zeikus, J.G. Ligninolytic enzyme system of Phanaerochaete chrysosporium: Synthesized in the absence of lignin in response to nitrogen starvation. J. Bacteriol. 1978, 135, 790-797. [PubMed]

45. Srivastava, S.K.; Shrivastava, A.K.; Jain, N. Degradation of black liquor, a pulp mill effluent by bacterial strain Pseudomonas putida. Ind. J. Exp. Biol. 1995, 33, 962-966.

46. Jain, N.; Shrivastava, A.K.; Srivastava, S.K. Degradation of black liquor, a pulp mill effluent by bacterial strain Acinetobacter calcoaceticus. Ind. J. Exp. Biol. 1997, 35, 139-143.

47. Alekhina, M.; Ershova, O.; Ebert, A.; Heikkinen, S.; Sixta, H. Softwood kraft lignin for value-added applications: Fractionation and structural characterization. Ind. Crops Prod. 2015, 66, 220-228. [CrossRef] 